\title{
TANTANGAN DAN HAMBATAN HUBUNGAN KONTRAKTUAL ANTARA PERUSAHAAN KAWASAN INDUSTRI DAN PERUSAHAAN INDUSTRI (Studi Kasus Perjanjian antara PT JIEP dengan PT Yamaha Indonesia)
}

\author{
Yusuf Yuniarto \\ Email: yusuf.yy18@gmail.com \\ Mahasiswa Fakultas Hukum Universitas Sebelas Maret Surakarta \\ Dona Budi Kharisma \\ Email: donabudikharisma@staff.uns.ac.id \\ Dosen Fakultas Hukum Universitas Sebelas Maret Surakarta
}

\begin{abstract}
This article aims to know the contractual relationship between PT JIEP and PT Yamaha Indonesia in the perspective of the Book of Private Law Regulation and Government Regulation Number 142 of 2015 concerning Industrial Estates and challenges and obstacles faced by PT JIEP in carrying out contractual relationships. This research is a descriptive empirical law research. The research location is at PT JIEP. The research types and source of data include primary and secondary data. Methods for data collection are through depth interview and literature study. The technique analysis data is qualitative with interactive model analysis. The results of this research shows that the Challenges and obstacles faced by PT JIEP in conducting contractual relations is: (a) lack of the active role for PT JIEP in Industrial Relations Disputes; and (b) there is no clear action written in the agreement if there is delay in lease payment and deposit.
\end{abstract}

Keywords: Legal Contract; Industrial Area; Industrial Relation Dispute.

\begin{abstract}
Abstrak
Artikel ini bertujuan untuk mengetahui hubungan kontraktual antara PT JIEP dan PT Yamaha Indonesia ditinjau dalam perspektif KUHPerdata dan Peraturan Pemerintah Nomor 142 Tahun 2015 tentang Kawasan Industri dan tantangan dan hambatan yang dihadapi oleh PT JIEP dalam menjalankan hubungan kontraktual. Penelitian ini merupakan penelitian hukum empiris yang bersifat deskriptif kualitatif. Lokasi penelitian dilakukan di PT. Jakarta Industrial Estate Pulogadung. Jenis dan sumber data penelitian ini meliputi data primer dan data sekunder. Teknik pengumpulan data melalui studi lapangan dan studi kepustakaan. Teknik analisis data dilakukan secara kualitatif dengan model analisis interaktif. Hasil penelitian ini menjelaskan Tantangan dan hambatan yang dihadapi oleh PT JIEP dalam melakukan hubungan kontraktual adalah: (a) kurangnya peran PT JIEP secara aktif dalam Perselisihan Hubungan Industrial; dan (b) tidak adanya tindakan yang jelas yang tertulis dalam perjanjian apabila terdapat keterlambatan pembayaran sewa dan deposit.
\end{abstract}

Kata Kunci: Kontrak; Kawasan Industri; Perselisihan Hubungan Industrial.

\section{A. Pendahuluan}

Peran industri dalam menjadi tulang punggung perekonomian nasional dan memberikan nilai tambah bagi sumber daya alam Indonesia yang melimpah dari kekayaan hasil laut, pertanian, perkebunan, hutan, tambang, dan sebagainya, yang semuanya menjadi barang kebutuhan masyarakat dan sebagian dijual ke luar negeri, menambah daya tarik bagi para pelaku usaha asing untuk mengembangkan usahanya di Indonesia. Sektor industri pengolahan masih memiliki peran strategis dalam perekonomian nasional. Hal ini terlihat dari kontribusi sektor industri terhadap serapan tenaga kerja, kesejahteraan masyarakat, dan penerimaan negara. Menteri Perindustrian Airlangga Hartarto mengatakan dalam hal penyerapan tenaga kerja, hingga Agustus 2017 tercatat sebesar 17,01 juta orang bekerja di sektor industri atau sekitar $14,05 \%$ dari total tenaga kerja di 
Indonesia. (https://ekonomi.bisnis.com/read/20171127/257/713008/sektor-industri-masih-topangperekonomian, diakses pada 7 Desember 2018). Hal ini sejalan dengan tujuan dari Perindustrian yang tertuang dalam Pasal 3 poin a Undang-Undang Nomor 3 Tahun 2014 tentang Perindustrian yang menjelaskan bahwa perindustrian diselenggarakan dengan tujuan mewujudkan industri nasional sebagai penggerak perekonomian nasional. Maka dari itu untuk mencapai tujuan tersebut maka dibentuklah sebuah kawasan industri sebagai pemusatan kegiatan industri yang dilengkapi dengan sarana dan prasarana penunjang kegiatan industri itu sendiri.

Kawasan industri memiliki peran yang sangat penting untuk mendukung kegiatan perindustrian. Perkembangan sektor industri di Indonesia, khususnya di Jakarta sudah mulai dapat disoroti, terutama PT JIEP yang berlokasi di Pulogadung. Pulogadung dapat menjadi pilihan lokasi kawasan industri yang utama karena lokasinya yang strategis serta mempunyai akses transportasi yang memadai sehingga dapat menunjang kegiatan distribusi. Sebagai kawasan industri pertama di Indonesia, Kawasan Industri pulogadung pada awalnya dikelola melalui wadah proyek, dengan nama Proyek Industrial Estate Pulogadung milik Pemerintah Propinsi DKI Jakarta. Sejalan dengan perkembangan arus penanaman modal di Indonesia yang meningkat, khususnya di DKI Jakarta, maka lingkup kerja Proyek Industrial Estate Pulogadung semakin kompleks. Dan untuk menunjang perkembangan kebutuhan masyarakat industri, Pemerintah memandang perlu dilakukan penyesuaian diri, baik dari segi kelembagaan maupun permodalannya.

Pasal 2 Peraturan Pemerintah Nomor 142 Tahun 2015 tentang Kawasan Industri menjelaskan bahwa pembangunan kawasan industri bertujuan untuk:

1. Mempercepat penyebaran dan pemerataan pembangunan Industri;

2. Meningkatkan upaya industri yang berwawasan lingkungan;

3. Meningkatkan daya saing investasi dan daya saing industri; dan

4. Memberikan kepastian lokasi sesuai tata ruang.

Untuk mewujudkan tujuan dari kegiatan perindustrian di Indonesia, maka pelaksanaan segala hal yang berkaitan dengan kawasan industri memerlukan adanya peran Perusahaan Kawasan Industri dan Perusahaan Industri. Perusahaan Kawasan Industri adalah perusahaan yang mengusahakan pengembangan dan pengelolaan kawasan industri, sedangkan Perusahaan Industri adalah pihak yang melakukan kegiatan di bidang usaha Industri di dalam Kawasan Industri. Namun pada pelaksanaan pencapaian tujuan dari dibentuknya kawasan industri antara kedua belah pihak harus didasari dengan sebuah perjanjian. Hal ini dikarenakan hubungan hukum yang terjadi antara kedua belah pihak ini merupakan hubungan antara pihak pengelola, yang memiliki wewenang penuh atas kawasan yang dimilikinya dengan tenant, pihak yang bersedia untuk melaksanakan kebutuhannya dalam kawasan yang dikehendaki dengan mematuhi tata tertib yang telah ditentukan oleh pihak pengelola.

Pedoman dalam melakukan kegiatan perindustrian bagi para pihak harus diperhatikan dari dua sudut pandang. Perjanjian yang terjadi antara PT JIEP dengan PT Yamaha Indonesia merupakan suatu perjanjian dalam ranah bisnis. Maka dari itu perlu diperhatikan aspek dalam kegiatan bisnis yang penting yaitu sebuah perjanjian pada umumnya yang sesuai dengan ketentuan-ketentuan yang berlaku secara umum yang disusun dalam sebuah kontrak antara PT JIEP dengan PT Yamaha Indonesia. Namun perlu diperhatikan juga bahwa dalam Peraturan Pemerintah Nomor 142 tentang Kawasan Industri telah diatur kewajiban bagi pihak Perusahaan Kawasan Industri dan Perusahaan Industri, yang mana kewajiban ini mengatur lebih spesifik terkait pedoman yang harus dipenuhi oleh para pihak terkait dengan teknis dalam pelaksanaan kegiatan perindustrian dalam kawasan industri.

Kajian mengenai analisis hubungan kontraktual antara PT JIEP dengan PT Yamaha Indonesia penting untuk dikaji karena hubungan hukum antara PT JIEP dengan PT Yamaha Indonesia sangatlah penting sebagai pelaksana kegiatan perindustrian dalam suatu kawasan. Kedua pihak masing-masing memiliki fungsi yang berbeda. Namun ketika keduanya sudah saling terikat dalam sebuah kontrak tentu ada hal-hal yang harus diselaraskan demi pencapaian tujuan baik secara 
kolektif. Dengan adanya pengaturan yang jelas dalam kontrak, para pihak tentu dapat bertindak sesuai dengan fungsinya, terutama jika di suatu saat terjadi sebuah konflik dalam lingkup kawasan industri seperti pencemaran lingkungan, ataupun pencegahan jika terjadi kerusuhan yang disebabkan oleh para buruh.

\section{B. Metode Penelitian}

Merujuk pada judul dan pendahuluan, maka jenis penelitian yang digunakan penulis adalah penelitian hukum empiris. Penelitian hukum empiris, yaitu penelitian hukum yang dilakukan dengan pengumpulan datanya dari data primer atau data yang diperoleh langsung dari subyek penelitian, yang dilakukan baik melalui pengamatan, maupun wawancara langsung (Salim HS, 2013:26). Penelitian ini menggunakan bentuk penelitian deskriptif kualitatif. Menurut H.B Sutopo (2006: 179), "penelitian deskriptif kualitatif yaitu penelitian yang mengarah pada pendeskripsian secara rinci dan mendalam baik kondisi maupu proses, dan juga hubungan atau saling keterkaitannya mengenai hal-hal pokok yang ditemukan pada sasaran penelitian". Dalam penelitian ini, penulis menggunakan pendekatan Kualitatif. Peneliti menekankan catatan yang menggambarkan situasi sebenarnya guna mendukung penyajian data (HB Sutopo, 2006: 35).

\section{Hasil Penelitian dan Pembahasan}

\section{Pertanggungjawaban PT JIEP atas Perselisihan Hubungan Industrial}

Dalam Kawasan Industri terdapat dua perusahaan. Perusahaan tersebut adalah Perusahaan Kawasan Industri dan Perusahaan Industri. Perusahaan Kawasan Industri adalah perusahaan yang mengusahakan pengembangan dan pengelolaan kawasan industri, sedangkan perusahaan industri adalah setiap orang yang melakukan kegiatan di bidang usaha industri di dalam Kawasan Industri (Dr. AL. Sentot Sudarwanto, 2018: 64). Pengertian masingmasing tentang Perusahaan Kawasan Industri dan Perusahaan Industri juga dijelaskan dalam Peraturan Pemerintah Nomor 142 Tahun 2015 tentang Kawasan Industri, yaitu:

\section{Pasal 1 Angka 5:}

"Perusahaan Kawasan Industri adalah perusahaan yang mengusahakan pengembangan dan pengelolaan kawasan Industri."

\section{Pasal 1 Angka 2:}

"Perusahaan Industri adalah setiap orang yang melakukan kegiatan di bidang usaha Industri yang berkedudukan di Indonesia."

Pengaturan tentang hak dan kewajiban masing-masing pihak diatur dalam Peraturan Pemerintah Nomor 142 Tahun 2015 tentang Kawasan Industri. Meskipun pada dasarnya perjanjian yang terjadi antara dua pihak merupakan perjanjian antara pengelola dengan penyewa, namun kedua belah pihak memiliki kewajiban yang harus dijalankan dalam rangka pelaksanaan kegiatan industri yang sesuai dengan tujuan yang telah diatur oleh perundangundangan.

Perusahaan Industri memiliki peran sebagai pelaku utama kegiatan perindustrian dalam sebuah kawasan industri. Oleh karena itu hubungan industrial harus dijaga dengan baik.

Sengketa dalam hubungan industrial kerap terjadi dengan berbagai jenis faktor. Fabio Sforzi menyatakan (Fabio Sforzi, 2015: 16):

"As the industrial district concept spread and became popular in various academic circles, including among economists, sociologists, historians, and management theorists, disputes about various aspects of it arose." 
Apabila diterjemahkan, Fabio Sforzi menyatakan bahwa seiring dengan konsep kawasan industri menjadi lebih dikenal dalam lingkup akademik yang lebih luas, baik bagi para pengamat ekonomi, sosiologi, sejarah, dan teori manajemen, sengketa dalam berbagai jenis aspek akan timbul. Perselisihan hubungan industrial saat ini kerap ditimbulkan oleh beberapa hal seperti permasalahan upah, fasilitas pekerja, pemutusan kerja secara sepihak, Jaminan Sosial Tenaga Kerja, upah lembur, dan lain-lain.

Dalam menjaga perselisihan hubungan industrial, perusahaan kawasan industri memiliki peran yang strategis. Dengan fungsi Perusahaan Kawasan Industri sebagai pengelola dan bertanggung jawab terhadap seluruh kegiatan yang di dalam kawasan industri, Perusahaan Kawasan Industri dapat menjadi jembatan bagi pihak Perusahaan Industri dengan pekerja. Peran Perusahaan Kawasan Industri dalam hubungan industrial sudah diatur dalam Pasal 35 Ayat 4 Peraturan Pemerintah Nomor 142 Tahun 2015 tentang Kawasan Industri, yang berbunyi:

"Pengelola Kawasan Industri wajib memfasilitasi hubungan industrial bagi Perusahaan Industri yang berada di dalam Kawasan Industri."

Peran memfasilitasi dalam pasal ini kemudian dijelaskan lebih lanjut yang dikatakan bahwa Perusahaan Kawasan Industri memfasilitasi hubungan industrial berupa penyediaan ruang, membentuk forum dan melakukan pertemuan rutin. Hal ini menjadi permasalahan yang dihadapi oleh Perusahaan Kawasan Industri, yaitu fungsinya sebagai fasilitator dalam hubungan industrial yang dirasa kurang efektif. Dengan ditetapkannya fungsi dari Perusahaan Kawasan Industri yang hanya sebagai fasilitator hal ini dapat menjadi kendala bagi Perusahaan Kawasan Industri, mengingat bahwa tanggung jawab yang dimiliki sebagai penanggung jawab untuk mengelola kawasan industri. Dengan besarnya tanggung jawab tersebut maka Perusahaan Kawasan Industri harus memiliki peran penting dalam memfasilitasi perselisihan hubungan industrial yang terjadi. Tidak hanya sekedar untuk menyediakan ruang dan mengatur jadwal untuk pertemuan.

Terkait tentang peran PT JIEP dalam perselisihan hubungan industrial, Reynna selaku Head of Corporate Legal PT JIEP mengatakan memang tidak banyak yang bisa dilakukan oleh pihak PT JIEP karena pada dasarnya sengketa yang terjadi antara buruh dan perusahaan itu sebenarnya harus diselesaikan langsung oleh pihak tenant yang mempekerjakan buruh tersebut. Selama ini perselisihan yang terjadi antara buruh dengan tenant diselesaikan secara internal tanpa adanya peran dari PT JIEP, sehingga sejauh ini PT JIEP belum pernah mengadakan pertemuan rutin ataupun membentuk forum untuk perselisihan internal.

Namun apabila perselisihan yang terjadi antara buruh dengan pihak tenant yang terkait menyebabkan kerusuhan dengan melakukan demo maka itu merupakan tanggung jawab dari PT JIEP apabila demo yang terjadi berada di dalam kawasan industri. Reynna mengatakan bahwa belakangan ini demo yang disebabkan karena adanya perselisihan di sekitar kawasan industri sudah tidak pernah ada lagi. Namun demo yang masih terjadi saat ini hanyalah bersifat insidental untuk memperingati Hari Buruh Nasional. Untuk pelaksanaan demo ini pihak PT JIEP telah menyediakan sebuah fasilitas yaitu berupa lapangan luas sebagai tempat berkumpul para buruh untuk memulai demo insidental. Pihak keamanan juga dikerahkan untuk mengawal para buruh untuk mencegah tindakan yang bersifat anarkis.

\section{Keterlambatan Pembayaran Deposit dan Sewa}

Untuk menggunakan fasilitas yang ada di dalam kawasan industri Pulogadung terdapat prosedur yang telah ditetapkan oleh pihak PT JIEP. Apabila calon tenant telah bersedia untuk menggunakan fasilitas yang ada dalam kawasan industri, maka para pihak harus melaksanakan perjanjian dan kemudian pihak PT JIEP menjelaskan terkait tentang pembayaran deposit dan sewa. 
Prestasi adalah sesuatu yang wajib dipenuhi oleh debitur dalam setiap perikatan. Prestasi adalah objek perikatan. Dalam hukum perdata kewajiban memenuhi prestasi selalu disertai jaminan harta kekayaan debitur. Dalam Pasal 1131 dan 1132 KUHPerdata dinyatakan bahwa harta kekayaan debitur baik yang bergerak maupun tidak bergerak, baik yang sudah ada maupun yang akan ada, menjadi jaminan pemenuhan utangnya terhadap kreditur.

Dalam SPPT terkait tentang biaya sewa dan deposit telah di atur dengan istilah yang berbeda, yaitu: BIAYAPEMANFAATANTANAHDAN CARAPEMBAYARANNYA. Dalam klausula ini tidak disinggung terkait dengan pembayaran deposit. Reynna mengatakan bahwa dalam SPPT memang tidak diterapkan deposit karena obyek yang disewa adalah tanah. Berbeda dengan sewa properti yang memang dikenakan deposit, karena obyek yang disewakan adalah bangunan. Deposit digunakan untuk perbaikan-perbaikan jika masa sewanya berakhir.

Klausula ini juga tidak mengatur terkait tentang akibat dari keterlambatan pembayaran yang dilakukan oleh Pihak Kedua. Oleh karena itu, apabila terjadi keterlambatan pembayaran melewati batas waktu yang telah diberikan oleh PT JIEP, maka PT JIEP secara substansi tidak memiliki kejelasan atas tindakan lebih lanjut yang akan diambil.

\section{Simpulan}

Berdasarkan penjelasan hasil penelitian dan pembahasan, tantangan dan hambatan yang dihadapi oleh PT JIEP dalam melakukan hubungan kontraktual adalah kurangnya peran PT JIEP secara aktif dalam Perselisihan Hubungan Industrial yang terjadi dan bentuk pertanggungjawaban dari pihak PT JIEP karena pada dasarnya sengketa buruh harus diselesaikan dengan pihak perusahaan yang mempekerjakan buruh tersebut. Sehingga PT JIEP tidak membahas terkait tentang hubungan industrial dalam SPPT. Kemudian terkait tentang keterlambatan pembayaran sewa dan deposit PT JIEP hanya memberikan jangka waktu paling lambat untuk melakukan pembayaran dan tidak mencantumkan tindakan yang jelas apabila terjadi keterlambatan pembayaran. Hal ini dikhawatirkan akan menimbulkan permasalahan karena kurangnya pengaturan secara tegas.

\section{E. Saran}

Memperkuat fungsi Perusahaan Kawasan Industri tidak hanya sebagai fasilitator yang hanya menyediakan ruangan dan mengadakan forum, tapi juga melaksanakan tindakan yang bersifat preventif ataupun berperan sebagai mediator dalam perselisihan hubungan industrial. Kemudian PT JIEP juga harus menetapkan sanksi apabila terjadi keterlambatan pembayaran dalam klausula terkait tentang pembayaran dalam SPPT sebagai payung hukum bagi PT JIEP untuk melakukan tindakan secara tegas terkait dengan pembayaran sewa dan deposit.

\section{F. Daftar Pustaka}

\section{Buku}

Arfiana Novera, dan Meria Utama. 2014. Dasar-Dasar Hukum Kontrak dan Arbitrase. Malang: Tunggal Mandiri.

Dr. AL. Sentot Sudarwanto, Dona Budi Kharisma, Ambar Budhi Sulistyawati. 2019. Hukum Perindustrian Indonesia. Yogyakarta: Thafa Media

Hasanudin Rahman. 2003. Contract Drafting (Seri Keterampilan Merancang Kontrak Bisnis). Bandung: PT Citra Aditya Bakti.

Mariam Darus Badrulzaman. 2001. Kompilasi Hukum Perikatan. Bandung: Citra Aditya Bakti.

Peter Mahmud Marzuki. 2011. Penelitian Hukum. Jakarta: Kencana Prenada Media Group. 
Salim HS. 2002. Teori dan Teknik Penyusunan Kontrak Publisher. Jakarta: Direktorat Jenderal Pendidikan Tinggi Depdiknas.

Salim HS. 2006. Perkembangan Hukum Kontrak diluar Hukum Perdata. Jakarta: PT Raja Garafindo Persada.

Salim HS. 2013. Penerapan Teori Hukum pada Penelitian Tesis dan Desertasi. Jakarta: PT Raja Grafindo.

Subekti. 2002. Pokok-Pokok Hukum Perdata. Jakarta: Intermasa.

H.B Sutopo. 2006. Metodologi Penelitain Kualitatif Dasar Teori dan Terapannya dalam Penelitian. Surakarta: UNS Press.

Soerjono Soekanto. 2014. Pengantar Penelitian Hukum. Jakarta: UII Press.

Zainuddin Ali. 2016. Metode Penelitian Hukum, Jakarta: Sinar Grafika.

Jurnal

Anthony T. Kronman. 1989. "Contract Law and the State of Nature". Journal of Law, Economic, \& Organization. Vol. 1 No. 1. England: Oxford University

Dahana Pamungkas, Suryanto. 2018. "Perkembangan Rencana Pembangunan Kawasan Industri Sentolo (2005-2013)". Jurnal Khasanah IImu. Vol. 9 No. 1 Maret 2018. Yogyakarta: Universitas Gadjah Mada (UGM).

Donald J. Schepker, Won-Yong Oh, Aleksey Martynov, Laura Poppo. 2014. "The Many Futures of Contracts: Moving Beyond Structure and Safeguarding to Coordination and Adaptation". Journal of Management. Vol. 40 No. 1, January. Canada: University of Calgary.

Ery Agus Priyono. 2014. "Aspek Keadilan dalam Kontrak Bisnis di Indonesia (Kajian pada Perjanjian Waralaba)". Law Reform. Volume 14, Nomor 1. Semarang: Universitas Diponegoro.

Fabio Sforzi. 2015. "Rethinking The Industrial District: 35 Years Later". Journal of Regional Research. Italy: University of Parma

M. Muhtarom. 2014. "Asas-Asas Hukum Perjanjian: Suatu Landasan dalam Pembuatan Kontrak". SUHUF, Volume 26, Nomor 1, Surakarta: Universitas Muhammadiyah Surakarta.

Mark M. Suazo, Patricia G. Martinez, Rudy Sandoval. "Creating Psychological and Legal Contracts Through Human Resource Practices: A Signaling Theory Perspective". Human Resource Management Review, Volume 19, Issue 2, June 2009

Timoticin Kwanda. 2000. "Pengembangan Kawasan Industri di Indonesia". Dimensi Teknik Arsitektur. Vol. 28, No. 1. Surabaya: Universitas Kristen Petra.

Yunita Ismail. 2016. "Kebijakan Pembangunan Kawasan Industri yang Berwawasan Lingkungan (EcoIndustrial Park)". Firm Journal of Management Studies. Vol. 1 No. 1 2016. Jakarta: President University

\section{Perundang-Undangan}

Kitab Undang-Undang Hukum Perdata

Undang-Undang Nomor 3 Tahun 2014 tentang Perindustrian

Peraturan Pemerintah Nomor 142 Tahun 2015 tentang Kawasan Industri

Peraturan Menteri Perindustrian RI Nomor 40/M-IND/PER/6/2016 tentang Pedoman Teknis Pembangunan Kawasan Industri 


\section{Internet}

http://industri.bisnis.com/read/20170407/257/643370/kemenperin-dorong-ikm-beroperasi-di-kawasanindustri

http://unido.org/who-we-are/unido-brief

https://www.academia.edu/24976311/SEJARAH_YAMAHA_MUSIK_DI_INDONESIA

https://ekbis.sindonews.com/read/1279502/33/ekonomi-indonesia-2017-ditopang-sektorindustri-1517815324

https://ekonomi.bisnis.com/read/20171127/257/713008/sektor-industri-masih-topang-perekonomian https://jiep.co.id/id/ 